\title{
Abject (M)Othering: A Narratological Study of the Prison as an Abject and Uncanny Institution
}

\author{
Tea Fredriksson $^{1}$ (D) \\ Published online: 18 September 2018 \\ (c) The Author(s) 2018
}

\begin{abstract}
The present study investigates how prison comes across as a culturally constructed imaginary. Drawing on narratological methodologies, the study discusses prison as simultaneously real and imagined in society's ongoing communication with and about itself. Through an investigation of how prison is presented in autobiographical prison literature, the study shows how culturally held fears of imprisonment surface in terms of abjection and uncanniness. Previous prison studies have discussed this in terms of civil death and subsequent resurrection. Unlike previous studies, the present study employs the monstrousfeminine motif as a critical device in order to redefine the understanding of prison as abject and uncanny in patriarchal societies. An implementation of the monstrous-feminine motif enables a reading of the prison's particular form of punishment as one that entails incorporation and assimilation; rather than operating on a patriarchal principle of exclusion.
\end{abstract}

\section{Imaginary Realities}

Cultural criminology has an established interest in engaging with the socially constructed meanings which underpin issues of crime and control (Ferrell 2013). Moreover, scholars within a gothic subset of cultural criminology have pointed out the usefulness of employing a narratological framework in investigations of such meanings (Ingebretsen 2007; Picart and Greek 2007; Surette 2007; Sothkott 2016). However, emotions such as the cultural anxieties inherent to meaning-making have received less attention than the defining and organizing processes which confer meaning onto objects of criminological interest; such as prison. This paper conducts a narratological analysis of prison autobiographies, in a critical discussion of how such narratives manifest cultural anxieties linked to prison.

Cultural anxieties permeating prison show themselves through narratives of transgression into monstrosity and otherness, which is evident in culture as well as crime policy (Garland 1990; Smith 2008). Furthermore, the historical ties between prison and the horrors of gothic fiction have influenced prison reform as well as literary and cinematic prison depictions (Fiddler 2011a, b). Over time, this inheritance of horror has become a merger of fact and fiction; ingraining prison in popular culture, and popular culture in the public's

Tea Fredriksson

tea.fredriksson@criminology.su.se

1 Department of Criminology, Stockholm University, Stockholm, Sweden 
perception of prison, to such an extent that frightening myths and stereotypes are considered facts about prison life (Cecil 2015). A telling example of prison's gothicity and this interchangeability of fact and fiction is the history of the prison's architectural affinity with gothic conventions. The architecture terrible of nineteenth-century prisons was deliberately designed to mirror gothic castles; the exterior artistically modelled to convey a fearful image of incarceration through the implementation of details such as spikes and stone statues of tortured convicts (Garland 1990). The explicit aim of this design was to add fuel to the fires of public superstition; inspiring horror stories which would render prison frightening to the public (Fiddler 2011a; Smith 2009). Effectively, prison exteriors were designed as the abject, monstrous other to proper, civilized society. Prison was thus visibly ejected from society as abject, while simultaneously being displayed for public view; functioning as an embodiment of the meaning of imprisonment aimed at eliciting — and designed based on familiarity with—gothic imaginaries and the horrors tied to them (Garland 1990). The façade thus made for an uncanny double of what was supposed to go on behind it; an embodiment of the meaning of punishment. The underlying narrative that structures the imaginary side of prison is thus arguably built on a gothic foundation.

While modern prisons lack the frightening exterior of the past, cultural criminology has shown how contemporary media is saturated by prison imagery perpetuating the same imagined realities as those projected by the aesthetic of Victorian prisons (Cecil 2015; Fiddler 2007; Smith 2008). Horror iconography and gothic narrative conventions are deeply embedded in the prison's communicative function; a phenomenon that comes across most clearly in how it is depicted in art and culture (Garland 1990; Smith 2008). Art and culture mark prison's difference from the remainder of society; inspiring and perpetuating much the same horror stories as nineteenth century prison's architecture terrible (Fiddler 2007). For society to differentiate itself from prison and render it frightening is a prerequisite for using the threat of imprisonment as an ordering (and othering) practice (Smith 2008, 2009). Perhaps more importantly, this differentiation allows society to maintain a sense of superiority and cleanliness in relation to prison and its inhabitants as a source of social defilement or pollution. Within this framework, prison has been imagined and understood as a patriarchal institution, enforcing state-ordered punishment-qua-masculinity (Smith 2008, 2009; Wacquant 2010). However, this view risks obscuring rather than unveiling the underlying anxieties that shape the sociosymbolic aspects of prison, which is something the present paper seeks to elucidate through a narratological analysis of the gothicity of prison autobiographies.

\section{Prison as a Gothic Imaginary}

Prison has been explained as an abject other to society; depicted as a living tomb where inmates persevere as ghosts, zombies or monsters, existing in a liminal state of living death (Smith 2009). Prison is thus both a space of safety, since it keeps the monsters at bay-and a site of horrors, envisioned as a dark tomb for live burials. This theme of tombs and live burials renders prison uncanny; as the "buried, repressed, repository of social fears" (Fiddler 2007). Uncanniness is a helpful tool for exploring the liminality of imprisonment as both life and death; cleanliness and pollution; safety and fear. A pertinent aspect of this liminality pertains to the uncanniness of fears of the tomb as a substitute for anxieties centred on the womb. Prison's standing as the abject other is thus by no means solid; instead, prison uncannily shifts out of this abject imaginary position and moves towards a more 
liminal standing where the whys and wherefores of its terrors come into question. It is this simultaneously abject and uncanny aspect of prison that the present study aims to explore.

As an othering institution, such as it manifests in society's ongoing conversation with and about itself through art and culture (Garland 1990), prison arguably functions as an expression of the abject other which society needs to exist in opposition to in order to maintain its sense of cleanliness, identity and hierarchical superiority. The hierarchical aspect of abjection as othering was originally defined by Kristeva as identity-forming practices pertaining to masculine and feminine identities in patriarchal societies, where abjection functions as an expression of power hierarchies through an othering and repression of what is considered to be feminine (1982). This identity-forming practice, entering into the symbolic order, is conceptualized as a breaking free from the feminine, maternal, pre-symbolic. The maternal is thus rendered abject. However, it is not the only abject reminder of the subject's pre-symbolic origins. Dead bodies; spoiled food; or bodily fluids are all abject as well, as they highlight the subject's own materiality and frailty. This kind of horror iconography is not uncommon in prison depictions (Cecil 2015; Fleisher and Krienert 2009; Smith 2008). Even academic prison discourse is rife with iconography derivative of the gothic genre in its articulation of the cultural anxieties regarding punishment as an ordering, and othering, practice (Fiddler 2007; Smith 2008, 2009). For instance, prison scholarship has been accused of ignoring inmates' experiences of "the horrors of prison, [...] the smell of fear and noise of desperation known so well by the men and women that live in cages" (Richards 2013:377). Such critique laments the lack of horror in prison scholarship through gothic terminology; thus highlighting gothicity's surreptitious ubiquity in prison discourse.

\section{Studying Prison's Gothicity}

In redefining the whys and wherefores of prison's particular form of punishment as abject and uncanny, the present study calls on the developments made in studies of cultural expressions of punishment which have elaborated on how and why abjection occurs; redefining the frightening features of femininity in patriarchal societies (Creed 1993; Kramer 2000). These elaborations, uncannily questioning what was long held as familiar scholarship on abjection, entail a fundamental reconceptualization of why the femininely coded abject threatens to upset order and the identity of the collective or individual subject in patriarchal societies. The notion of punishment in general, and imprisonment in particular, as a feminine rather than masculine practice has been explored within this literature. However, this framework has yet to be applied to prison studies or to the social function of fictionalized prison realities, and as such the literature on prison as a site of abjective othering lacks these developments. ${ }^{1}$

In light of this discrepancy between developments of abjection as a critical device on the one hand and prison studies on the other, the present study aims to incorporate new conceptualizations of abjection into the understanding of prison's sociosymbolic function. To exemplify this framework, the present study conducts a narratological analysis of three autobiographical prison narratives. Autobiographies are important as a genre, regardless of

\footnotetext{
1 Importantly, neither the current study nor its cited predecessors ought to be read as being in agreement with ideas of femininity as naturally abject or of any trait as inherently feminine or masculine, but rather as exploring how patriarchal societies have constructed femininity as such.
} 
whether or not people with real experiences of prison wrote these books. Rather, it is the truth claim inherent to the commercial genre-based on a true story-that matters to public perception of such narratives.

\section{The Abject and Uncanny Prison}

The abject frightens because it disrespects borders and thus threatens individual, collective or national identity. Kristeva describes abjection as the response to threats of defilement and disorder; the abject is ejected in a process of boundary maintenance meant to protect identity. While not using abjection as his framework, Smith frames the culture of punishment in this manner by pointing out how punishment is an ordering practice aimed at cleaning up cultural disorder (2008:28). Further highlighting how it is not only prison or its inhabitants but rather the merger of the two that is socially imagined as abject, he describes prison as a "polluted institution" filled with "evil inmates" (2008:90). By virtue of being the place where criminals qua pollution are sent, prison itself becomes polluted. Likewise, by virtue of being sent to such an abject space, prisoners are marked as abject. Therefore, there is no easy way of distinguishing between the two, in terms of where the source of abjection begins and ends. The attempted boundary maintenance thus collapses into an uncanny liminality. The uncanny concerns itself with "the familiar, unfamiliarized" (Hurley 2007:141); with things which cause doubt regarding that with which we thought we were familiar. Looking at studies such as Smith's, we can see ideas about prison as a rehabilitative space aimed at betterment unfamiliarized.

The origin of uncanniness as an analytical framework is attributed to Sigmund Freud, who published his seminal work in 1919. There, he states that the uncanny "belongs to the realm of the frightening" (2003:123), but more importantly that that which frightens "is actually nothing new or strange, but something that was long familiar to the psyche and was estranged from it only through being repressed" (2003:148). The uncanny thus frightens by bringing about a return of the repressed, it is "that species of the frightening that goes back to what was once well known" (2003:124), but has hitherto been denied. Much like abjection deals with expulsion, the uncanny deals with repressing things which pose a threat to a subject's sense of Self. Taken together, that which has been ejected as abject can return to haunt as something uncanny. The notion of a return highlights the temporality of uncanniness; the uncanny is not the reveal of the new, but rather the realization that something has been there all along (Trigg 2014:81). Uncanniness is thus a creeping, haunting anxiety - specters of the past are keenly felt and unsettling in the present. Additionally, this haunting can also stem from the future; both those dead and those not yet born can haunt and thus shape the meanings and inner workings of an institution (Royle 2003). In short, the uncanny unsettles borders surrounding supposedly familiar concepts pertaining to the definitions of self and other in a spatiotemporal sense.

Staples of uncanniness include automata and live burials, which question the boundaries between life and death; and doubles or doppelgängers, as they unfamiliarize the distinction between self and other. Uniforms which aim to separate officers from inmates is one way in which an uncanny prison environment, in part comprised of the othering of prisoners as abject to safeguard against their similarity to the collective self, is perpetuated. The insistence on horror iconography in cultural and medial depictions of prison life is another aspect of this boundary maintenance (Cecil 2015). The interplay of repression or expulsion 
and return or unfamiliarization is made visible through such practices, as prison refuses to remain abject which necessitates further attempts at boundary maintenance.

Another notable scholar in cultural prison research, uncannily enough also named Smith, discusses abject prison imagery in a way which ties prison to uncanny notions of haunting. Seeing prison as an enveloping darkness, a "dungeon-tomb" where "cadaverous creatures exiled from the world" haunt its halls, "persisting as ghosts or monsters in a carceral living death" (2009:28). The gothic aestheticism in invoking such imagery is clear, and Smith's study goes on in the same vein; describing prison as a "dark house of ghosts and monsters" (2009:29). Prison here becomes conceptualized as a space which turns inmates into animated corpses, only to enact "harrowing forms of resurrection" (2009:61; 209). Imprisonment envisioned as living death and subsequent resurrection makes prison that part of the societal body which turns inmates into "cadaverous creatures" (2009:28); non-people who exist as both dead and alive, excluded from society. The haunting aesthetic presented in Smith's study is not only brought about by the conceptualization of inmates as the living dead; rather it is tied up in how prison space turns them into such abject monstrosities. That which is ejected by the body as abject, such as blood or excrement, is associated with boundary maintenance (Kristeva 1982). Such corporeal waste qua horror iconography relates to how prison has historically been imagined as a bloody, filthy "catacomb of rejection" (Smith 2009:5); perpetuating the idea of prison as abject to the societal body. This idea of prison as a site of r/ejection will be explored further in the present study, as it is my contention that ejecting the abject, as well as creating or receiving it, is an important aspect of how prison can be reimagined as abject in a new sense-namely as the monstrous womb of said societal body.

Previous studies have dealt with the notion of prison as a uterine space (Fiddler 2007; Pheasant-Kelly 2013). The conceptualization of imprisonment in enclosed space as symbolic of the womb implies an infantile status and a potential for subsequent rebirth for its inhabitants. Fiddler suggests two ways of "examining the uterine space of the prison. It can either be seen as a nurturing, maternal space or as the locus of a rebirth" (2007:198). I would like to propose a third option, namely that of viewing prison as an expression of the monstrous womb; "attempting to create new life" through reform and rebirth, but succeeding "only in creating monsters" (Creed 1993:56). Expanding on Kristeva's theory of abjection, Creed critiques the traditional view of femininity as abject, emphasizing that a reworking of why femininity is abject to patriarchal societies questions the assumption that femininity equates passivity or victimization. In Creeds view, woman is terrifying not because she is castrated, lacking something essential to the masculine subject position as is the view in Freudian psychoanalysis, but rather because she castrates (1993). As Creed puts it, this reworking "undermines Freud's theories that woman terrifies because she is castrated and that it is the father who alone represents the agent of castration within the family" (1993:8). Instead, femininity terrifies because of its monstrosity. Smith calls for the development of "more universal, generalizable themes for a cultural criminology of punishment" (2008:7), and it is my contention that the monstrous-feminine is one such theme.

Within the monstrous-feminine framework, femininity is frightening because it threatens to punish; not, as is traditionally believed, because it presents an example of what happens if punishment is acted out. Instead, this view positions femininity as that which wields the power to castrate through incorporation-to devour, disrespecting and dissolving the borders of identity. Specifically, this feminine, castrating potential is discussed as an embodiment of the monstrous-feminine and the maternal castrator; "the castrating mother takes back the life she once created" (1993:82). Creed emphasizes how, "[u]nlike the female genitalia, the womb cannot be constructed as a 'lack' in relation to the penis. The womb 
is not the site of castration anxiety. Rather, the womb signifies 'fullness' or 'emptiness', but always as its own point of reference" (Creed 1993:27, emphasis in original). The monstrous womb motif thus expresses abject femininity as a threatening and powerful agency; not a frightening, passive example of something lacking or less-than. This motif is culturally envisioned as a "voracious maw, the mysterious black hole that threatens to give birth to equally horrific offspring as well as threatening to incorporate everything in its path" (Creed 1993:27). In short, this motif expresses abjection as punishment-as-femininity; as opposed to punishment of femininity or punishment as feminization. The monstrous womb motif expresses punishment-qua-femininity through the reclaiming, assimilation, and ejection of subjects. Art and culture often express this reclaiming of the subject through the metonymic or metaphorical use of imprisonment in enclosed space (Creed 1993). Such enclosed spaces are generally narrativized as frightening due to their suffusion with cruelty and secrets; their claustrophobic atmosphere; and their relative isolation from ordinary life (Creed 1993). These are spaces which threaten to dissolve the subject through physical and/or psychological manipulation and violence. Moreover, these enclosed spaces are not only horrifying due to their often dark, grimy and mysterious appearance; but also because of their simultaneous opposition to and doubling of safe, domestic space (Creed 1993).

Castration through incorporation is a key aspect of the monstrous-feminine. This motif is applicable to Sykes seminal writings on the pains of imprisonment (1958); showing prisoners as emasculated, infantilized, and civilly dead. Envisioned as exclusion from ordinary society, the pains of imprisonment centre on an enforced lack of masculinity brought about by several deprivations; autonomy, heterosexual relation, and so on. However, utilizing the monstrous womb as a critical device renders imprisonment as castration-qua-incorporation; opposing the idea of imprisonment as exclusion or civil death. Instead, imprisonment becomes a form of civil castration; a particularly potent form of effacement. Situated in this discussion, prison can be understood as abject in a new sense-as a site that devours and ejects, rather than kills and resurrects.

Maternal authority is any subject's first experience of learning to maintain a clean, proper and subordinate self within the confines of patriarchal society (Kristeva 1982); a lesson rehabilitation arguably seeks to reiterate. Thus, the rehabilitative purposes of prison can be viewed as expressing the same assimilative processes as those generally attributed to maternity in any patriarchal society. The monstrous-feminine thus frightens as it highlights the frailty of the patriarchal, symbolic order and its claim to citizens qua subjects (Creed 1993:83). Prison highlights this frailty as well, as those imprisoned represent a failure of said symbolic order; those imprisoned having failed to function as clean and proper members of the societal body. Prison here reads as symbolic of the maternal castrator; reclaiming the subject into a pre-symbolic state. Crimes against the symbolic order thus become interchangeable with crime in the traditionally legal sense.

\section{Methodology}

While previous research has provided a solid foundation with regards to the ongoing interplay of fact and fiction where the prison is concerned (Cecil 2015; Fiddler 2011a, b; Garland 1990; Smith 2008, 2009), this body of research is mainly positioned within a discourse of mis/representation, rather than one discussing feelings directed towards the prison and their cultural manifestation. While "the prison exists as both mythology and materiality" (Smith 2008:59), representation would imply distance between the thing itself as a material 
reality and the imagery showing it. This risks obscuring, rather than unveiling, the anxieties underlying the culturally imagined prison. To avoid this, the present study has adopted a psychoanalytical, narratological approach. This enables insight into the underlying anxieties the narratives might express through their presentation of fiction-as-fact. It also enables a reimagining of imprisonment as a feminine, rather than masculine, punishing practice.

This study regards texts as presentations of the emotionally charged imaginary, rather than representations of the real. Thus, the present study is not to be confused with convict criminology's aims of penetrating "the reality of [prisons as] distant social worlds" (Richards 2013:380; emphasis added). Rather, the present study concerns the imaginaries circulated among the general public; the fictions that (mis)inform our cultural understanding of prison. Therefore, prison-as-text is not construed as a representation of some other aspect of the prison; rather, it is the prison, such as it exists as a cultural imaginary in western society's ongoing conversation with and about itself. In keeping with viewing texts as presentations rather than representations, the present study does not evaluate autobiographical accounts in terms of reliability. Rather, autobiographies are viewed as fictionalized narratives, since they are tailored for entertainment purposes (Cecil 2015:201). The autobiographical genre thus occupies a liminal space of simultaneously factual and fictitious narrativization of prison. The shock value added to narratives by the truth claim inherent to the genre is what matters here, not whether or not these claims are actually true. Therefore, autobiographers are regarded as characters and narrators for the purposes of the analysis; not as authors or informants in a sociological sense.

For the purposes of the present study, three texts are considered: Newjack by Ted Conover; Orange is the New Black by Piper Kerman, and In the Belly of the Beast by Jack Henry Abbott. Titles were chosen based on popularity, public recognition and critical acclaim. The texts were subjected to repeated close readings, which involved looking at how prison space is narrativized; and how prison might in turn be presented in a manner intertextually intertwined with established horror iconography, rendering it abject and uncanny. Selection and coding of quotes was based on how they brought these themes to light, for example by focusing on bodily or psychological harm; dark, tight spaces; or the dissolution of identity.

\section{Prison as an Abject (M)Other}

Interestingly, Newjack ties the prison to notions of it being haunted by its future (see Royle 2003:56), through a discussion of expected expansions. Ted's narrative shows prison as a space that continues to "swallow thousands of inmates" even when already overcrowded; ever expanding (2011:202). He also talks about prison as entailing "suspended animation" for its inmates (2011:287), highlighting their state of being encapsulated by another into a state of non-life. The uterine aspects of prison space come across clearly in such imagery (comp. Fiddler 2007). This uterine prison is narrativized as an insatiable black hole, growing by any means necessary to accommodate its appetites. In this light, prison is the epitome of Creeds definition of the monstrous womb as a "voracious maw, the mysterious black hole that threatens to give birth to equally horrific offspring as well as threatening to incorporate everything in its path" (Creed 1993:27). Ted's narrative exemplifies the monstrous womb motif through envisioning prison as a voracious maw; prison policy being viewed as catering to its insatiable appetites. The narrative expresses anxiety regarding future prison expansions; since planning to expand and build new prisons several years into the future implies "planning for a child" (Conover 2011:233). These notions of the prison 
as a space that devours point to an understanding of prison as a space that incorporates and effaces; and that it is this incorporation into the particular prison environment which enables the deprivation of autonomy discussed in previous studies- not the exclusion from the remainder of society (Sykes 1958).

The notions of incorporation by, and assimilation into enclosed space which found the monstrous womb motif are exemplified in different ways in the explored texts; one of which being through a theme of dissolution. Newjack deals with prison experience as being akin to being immersed in "a big body of water"; as drops constituting a whole, individuals are "all in it together", equally subservient to prison rules regardless of their official status (Conover 2011:62). This narrative shows how easily the immersive prison experience leads to effacement of individuals regardless of their function. Inmates are absorbed into "one big green-clad undifferentiated mass" (Conover 2011:221); losing their individuality and turning into doubles of one another. Likewise, prison guards merge into a sea of grey uniforms; existing as mere automatons whose sole purpose is maintaining order (Conover 2011:274). Seeping through the stitches of uniforms meant to keep distinctions in place, prison here comes across as an immersive, permeating environment which disregards borders constituting rank and individuality; boundless in its deprivation of autonomy. This deprivation-as-dissolution is noticeable in Piper's narrative in Orange is the New Black as well. Once inside prison, she is stripped of her personal items, and thus of her Self:

[A prison guard] put my own clothes in a box - they would be mailed back to Larry, like the personal effects of a dead soldier [...]. In minutes I was transformed into an inmate.

\section{Kerman 2010:40}

Stripped of her identity, Piper comes to feel that she is "verging on a non-person" due to the loss of autonomy her imprisonment has brought about (2010:64). Likening her situation to that of a dead soldier, her identity is effaced by having been incorporated into the prison. Her narrative here suggests that once secluded in prison, her loss of autonomy is experienced as bearing similarities to non-life. This narrative thus lends itself to the idea of imprisonment as civil death; being transformed into an inmate is equated to a loss of life and selfhood. However, this loss is a transformative experience; becoming part of the prison, Piper dissolves as her individuality transforms into part of a whole through her inmate status.

Like Piper's narrative, Jack's also shows how prison incorporates and assimilates inmates. Along with being assimilated into prison himself, Jack further notes this gradual change in his fellow inmates:

They say that people who live together gradually begin to look alike. Married couples begin to "look" like one another because their facial expressions reflect an agreement about things around them, because their mannerisms and idiosyncrasies have become similar. They say it is a sign of genuine love - that the lover and the beloved grow into one. I have seen it. We all have. We all know it takes years of living together for lovers to become "look-alikes". Something deep within me, however, turns over in its grave each time I notice that I look like my "brothers" who have been in prison all their lives.

Abbott 1981:85; emphasis in original.

Here Jack, not unlike Ted, addresses a doppelgänger motif among inmates. In pointing out how he and his "brothers" have all been assimilated by prison, he also points out that 
they have become interchangeably similar to one another. By this enforced merger with one another, the prisoners' individuality dissolves. Additionally, by addressing his fellow inmates as brothers, Jack furthers the idea of prison as a metonymically maternal space. The metonymically maternal aspect is further evident in how Jack defines the state-raised convict; "the prisoner who grows up from boyhood to manhood in penal institutions" (Abbott 1981:11). Unlike prisoners who grew up free, who know that things are different outside of prison, "the state-raised convict has no conception of any difference" (Abbott 1981:12). Having been raised by prison, Jack, at age 37, still considers himself as "barely a precocious child" (Abbott 1981:13). The state-raised convict, then, becomes a kind of human temporal anomaly as a result of having been raised solely through imprisonmenthe is "a product of prison conditions" (Abbott 1981:24). As products of prison, these convicts are by and large products of the prison as an archaic mother. Creed describes the archaic mother as being able to (re)produce without the need of male involvement; she is "the point of origin and of end". She brings life, but also takes it back and devours it. The idea of state-raised convicts lends itself to the idea of prison as an archaic mother, since prison here becomes Jack's origin and end-prison produces as well as devours him.

Furthermore, an aesthetic generally associated with imprisonment is not uncommon for an environment to express the presence of the archaic mother. This presence is often visible in how narratives express the setting in which its events unfold. Such settings often consist of long, winding hallways; enclosed and/or isolated spaces; abject, bodily matter on walls, floors or ceilings; narrow passageways; or an air of constant supervision (Creed 1993:18-9; 23). We can see this in Jacks appropriately named narrative, In the Belly of the Beast:

My first acquaintance with punitive long-term solitary confinement had a more adverse and profound spiritual effect on me than anything else in my childhood.

I suffered from claustrophobia for years when I first went to prison. I never knew any form of suffering more horrible in my life.

The air in the cell vanishes. You are smothering. Your eyes bulge out; you clutch at your throat; you scream like a banshee. Your arms flail the air in your cell. You reel about the cell, flailing.

Then you suffer cramps. The walls press on you from all directions with an invisible force. You struggle to push it back. The oxygen makes you giddy with anxiety. You become hollow and empty. There is a vacuum in the pit of your stomach. You retch.

You are dying. Dying a hard death. One that lingers and toys with you.

The faces of guards, angry, are at the gate of your cell. The gate slides open. The guards attack you. On top of all that, the guards come into your cell and beat you to the floor.

Abbott 1981:25.

This kind of environment is constraining, claustrophobic, and threatening, which all goes in line with the archaic mother being a terrifying presence because she castrates-possessing "all-consuming, incorporating powers [...] to tear apart and reincorporate all life" (Creed 1993:22). Not infrequently, this tearing apart is enacted through proxies; exemplified above by the prison guards.

The idea of prison as an abject mother is also visible, albeit not articulated, in how supervision and rehabilitative ambition comes across as parental. Previous studies point out that "the gaze of the state" can be said to function as a key aspect of imprisonment; acting like the "parent [those incarcerated] never had" (Sloop 1996:2). This gaze manifests 
through the feeling of constant monitoring which imprisonment entails, giving it a panoptic air. Penal and parental discipline here effectively mirror one another; prisoners are equated to children while prison becomes the uncanny double of a parent. This creates a panoptic environment, permeated by invisible discipline made possible by feelings of constant supervision. This also makes prison an uncanny double of domesticity, in its dark mirroring of the safe space of the home. Maintaining order in this uncanny prison space is not so much an individual act as it is an enactment of assimilation into the prison itself; of being the hands that act on what this gaze perceives. Exemplifying this, Ted speaks of being "like the mother of a nightmarishly large brood of sullen, dangerous and demanding children" (Conover 2011:234). Here, prisoners are reduced to a childlike status by their environment (Sykes 1958), but furthermore these childlike inmates are rendered monstrous-while guards coalesce into a decidedly maternal whole. Being like a mother to the prison's nightmarish children, Ted functions as an extension of the prison itself. Moreover, this oneness with prison is presented as a feminine, maternal and frightening experience. Frightening, but not because of the inmates-qua-monstrous-children but rather because of what Ted himself has become as the enforcer of prison's equally monstrous rule. This abject (m)othering is brought about by his assimilation into prison, making it an expression of the monstrous womb motif both in terms of incorporation and maternal discipline (Creed 1993). The notion of prison as embodying a parental gaze can thus be viewed more specifically as an embodiment of the monstrous womb as maternal authority; exemplified by its power to reclaim and devour subjects. As a result, prisoners have no autonomous identity outside of prison as an abject, uterine space. Even if released, ejected into the world outside, Jack feels certain that he would return:

I would have returned, over and over again. I would have been a thief or a jive-talking dope fiend who has no idea of anything else in life except singing the blues and paying his dues in prison. Why? Because that is what the government, the state reared me from childhood to be; that is what adjusting to prison does to a man.

Abbott 1981:97; emphasis added.

The uncanny repetition of endless returns to the maternal here comes across less as a question of adjusting to prison and more one of being assimilated into it; castrated through incorporation. This is also alluded to during his transportation there, as Jack explains how he was told "that I was being sent there to be reduced to a punk, to be shorn of my manhood (Abbott 1981:79). Jack is being given an explicit reason for his imprisonment; being shorn of his manhood. Effectively, prison becomes the maternal castrator. The maternal castrator is also visible in Ted's narrative; to him prison is where, unavoidably, "grown men are infantilized" (Conover 2011:234). This ties into Sykes' view that imprisonment is a reduction of the individual's level of autonomy from adulthood to childhood; posing a threat to the prisoner's self-image (1958:75). However, this threat is arguably not one of castration understood as being cut off from the symbolic order; rather, the threat lies in being swallowed up by the monstrous-feminine.

Following the ideas being incorporated and assimilated is that of release. Imprisonment has been narrativized as a form of suspended animation, and ejection from this space thus becomes a "reworking of the birth scenario which is represented as a fearful experience"; where subjects exit a secluded space, "bursting forth into the unknown" (Creed 1993:56). Anxieties about what manner of others will burst forth as prison (r)ejects them is intertextually visible across the examined prison narratives. For instance, Ted expresses concern regarding what effect imprisonment has on those subjected to it: 
But can rite of passage possibly be the correct term for a kind of suspended animation that leaves you older, weaker, less sexually attractive, and less connected to community than before you went in?

\section{Conover 2011:287}

The text here shows anxieties about the effects of imprisonment. Reform is shown to imply deterioration, rather than improvement (Conover 2011:19). Those who are ejected back into society are imagined as returning subhuman; further aligning themes of re/birth with themes of un/death (see Smith 2009). Undesirable traits are distilled to the point where return from civil death is imagined as something more akin to traditional zombie iconography than to a rehabilitated citizen. There are similarities here between the dehumanization and demonization of prisoners in popular culture and another abject motif; the zombie. Detailing a disintegration of the brain, "the organ associated with the production and organization of identity" (Chaplin 2011:248), zombies serve as a symbolic expression of anxieties pertaining to abjection as well as uncanniness; standing as human bodies devoid of humanity. The loss of one's mind, along with the grime and filth of prison space (Kerman 2010:92), thus lends itself to notions of prison as a site that produces mindless monstrosities. While intending to reform, imprisonment instead threatens to turn individuals into abject, raw physicality; creatures of instinct rather than intellect:

It was easy to lose track of what day it was - there were no newspapers, no magazines, no mail, and since I avoided the TV rooms, no significant way to tell one day from the next. [...] I learned to understand the true punishment of repetition without reward. How could anyone do significant amounts of time in a setting like this without losing their mind?

\section{Kerman 2010:306}

Utilizing the monstrous womb motif as a critical device, this becomes an expression of fears that prison, while "attempting to create new life" through reform and rebirth, succeeds "only in creating monsters" (Creed 1993:56). This is further exemplified in Jack's narrative, as he points out that "by the time you get out—if you get out—you are capable of anything, any crime at all” (Abbott 1981:122, emphasis in original).

A final example of prison as a monstrous feminine, uterine space which dissolves and incorporates can be found in how The Belly of the Beast narrativizes the isolation cell; the hole. While firmly cementing a border between itself and the space around it, the hole dissolves the borders between inside and outside within itself. The lights are unavoidable, "present even when you close your eyes", visible through your eyelids it "throbs away in your mind" (Abbott 1981:29). The space thus seeps in; defying bodily borders and becoming coextensive with the mind of the inhabitant. Even if closing your eyes could shut the light out, it would do nothing to stave off the smell of the place from entering your nose. Since these lights are never extinguished, you cannot tell night from day. The only way to estimate the time spent in this space is by counting the number of times you have been fed. There is nothing on the walls to inspire one's imagination, and there is no toilet, bed, or running water. Further adding to, and perhaps the most important for, the particular atmosphere of this space is the floor. It tilts; shifting one's balance as it inclines towards the centre of the room. At the centre, there is a hole for waste disposal from which stains radiate outward; creeping across the floor, reaching for the room's inhabitant. While it asserts borders, as an isolating space apart from the ordinary, the hole is ambiguous as a site of boundary maintenance in that it also dissolves borders. The presence of foreign bodies is 
marked by what they left behind; their ejected abject becomes a proxy which enables the trace of previous inmates to inhabit the space in a temporally ambiguous way. They have been incorporated by the space to the point where they linger even when ejected from it. They are present, yet absent; in effect haunting the space; their presence permeating the air as a permanent stench:

[W]hat faces you is a cesspool world of murk and slime; a subterranean world of things that squirm and slide through a noxious sewage, piles of shit and vomit and piss. There is the smell of unwashed feet and nervous sweat of bodies foreign to yours, so closing your eyes gives no relief. If you are in that cell for weeks that add up to months, you do not ignore all this and live "with it"; you enter it and become a part of it.

Abbott 1981:29; emphasis added.

The hole, then, is not a space that merely isolates or excludes the prisoner. Moreover, it not only dissolves physical or temporal borders in its management of bodies in its particular time-space. This is a space that devours, making it a clear example of the monstrous womb motif. Jack cannot live with the space, or even as a separate entity within it-he becomes assimilated by it; entering and becoming a part of a maternal (w)hole.

\section{Implications of Abject and Uncanny Prison Imaginaries}

The present study set out to redefine the frightening aspects of prison as a collective imaginary through an investigation of prison autobiographies. As such, it addresses the lack of scholarship regarding "the horrors of prison" (Richards 2013:377), but from the point of view of autobiographies as a commercial, fictionalized genre, rather than as a source of reliable representations of prison life. The idea of horror stories as true stories is foundational for this genre, making prison autobiographies uniquely situated to impact public perception of prison. As such, the present study focused on what horrors are expressed, and how, in this merger of fact and fiction which arguably (mis)informs much of public perceptions of prison.

The analysis focused on fears and anxieties evident in the investigated texts. However, that should not be read as an argument that these are the only feelings expressed therein, although the popularity and pervasiveness of horror in prison imaginaries might tell us something about the public's views of and feelings towards prison and prison policy. As previous studies have pointed out, the overall aesthetic of prison imaginaries is one of terror and horror (Garland 1990; Smith 2008, 2009; Fiddler 2007, 2011a, b; Cecil 2015). As this study shows, these imagined realities show affinity with horror iconography in ways that invite a reimagining of prison as monstrous-feminine. As such, gothisized prison imaginaries play into patriarchal anxieties regarding punishment as violent, maternal discipline and the generative powers of the monstrous womb; conceiving and creating on its own, leaving masculine control both unnecessary and impossible (Creed 1993:27).

In the explored texts, prison has been shown to enact punishment-as-incorporation, depriving individuals of their autonomy and reducing them to an infantilized state; dissolving their individual boundaries. Anxieties regarding the state of inmates upon release show further affinity with the monstrous womb motif, as it ties into fears of re/birth as something monstrous. Rather than being a uterine space that offers maternal care or rebirth in any positive sense (compare Fiddler 2007), this study shows prison to be more in line 
with horror iconography that "presents us with a graphic, explicit, disturbing image of the mother carrying out the law, enforcing retribution" (Creed 1993:148). The present study finds that prison is culturally articulated as a space that punishes via incorporation while simultaneously ejecting subhuman subjects. Public prison anxieties thus entail both loss of identity through incorporation, fear of becoming the abject, as well as the creation of monstrosity through abortive attempts at rehabilitation; fear of the abject itself. While these anxieties are visible in cultural imaginings of prison, allusions to the penetrative violence associated with punishment-qua-masculinity are comparatively absent.

The monstrous womb motif demonstrates how prison comes across as a space that devours; making its form of punishment feminine. Rather than entailing carceral living death and resurrection (Smith 2009), the present study's framework offers an understanding of prison as incorporation into an isolating, infantilizing space serves as the "castration via incorporation"; which is indicative of the maternal castrator (Creed 1993:157). Prison thus comes across as a feminine presence, and more importantly, as aligned with fears of the archaic mother existing as her own point of reference. Prison is easily construed as a space that devours those who occupy it; a site where individual subjects are incorporated. This merges with Sykes' classic idea of imprisonment as a "deprivation of autonomy", since incorporation-qua-castration reduces the prisoner to the "weak, helpless, dependent status of childhood" (Sykes 1958:73, 75). Unlike Sykes pains of imprisonment, the monstrous-feminine view focuses less on the obstacles faced by heteronormative masculinity, and more on the imposing effects of prison as an overwhelming, sublime femininity.

Cultural expressions of the prison can be read as expressions of individual as well as collective fears of the castration via incorporation which imprisonment entails; "an infantile fear of the castrating, punishing parent" (Creed 1993:148). The view of inmates as infantile and awaiting rebirth is similar to what Smith pictured as carceral living death followed by "harrowing forms of resurrection" (2009:209). However, rather than a site of civil death for the individual subject, prison here becomes the space of its dissolution into non-life. The abject properties of prison thus indicate that imprisonment is not imagined as state ordered exclusion, but rather as the actions of a monstrous-feminine institution; castrating via incorporation.

The present study has shown texts to depict prison through use of traditional horror iconography; indicating that cultural presentations of prison serve to render it abject to the public in order to mark its difference. However, prison also clearly comes across as uncanny in its refusal to remain abject. This uncanniness is clear in how prison is shown as haunted in a temporal sense. Past, present and future become coextensive as a result of prison's insatiable appetites as a monstrous, voracious maw. The liminal qualities apparent is prison's dissolution of time, identities and even bodies make the borders which abjection aim to safeguard impossible to maintain. Prison is not only haunted by its long history and probable future of dehumanizing, incorporating practices. It also exerts a haunting presence through its similarities to the domestic. In effect, this links prison to other total institutions such as schools or hospitals; rendering them all uncanny in their similarities to one another in spite of their differing aims of punishment or care.

Prison's similarities to domesticity become unsettling due to a collectively held, preexisting understanding of prison as an abject other to domestic safety (Smith 2008, 2009; Garland 1990). The understanding of prison as abject, in turn, render notions of prison as rehabilitative or beneficial to society uncanny. As monstrous-feminine, prison becomes an institution of incorporation and assimilation to the point of unbecoming; rather than an institution of reintegration. As such, the monstrous-feminine could prove useful in the development of "generalizable themes for a cultural criminology of punishment" (Smith 
2008:7), as prison is arguably culturally imagined as the monstrous womb of the societal body.

\section{Compliance with Ethical Standards}

Conflict of interest The author declares that they have no conflict of interest.

Open Access This article is distributed under the terms of the Creative Commons Attribution 4.0 International License (http://creativecommons.org/licenses/by/4.0/), which permits unrestricted use, distribution, and reproduction in any medium, provided you give appropriate credit to the original author(s) and the source, provide a link to the Creative Commons license, and indicate if changes were made.

\section{References}

Abbott, J. H. (1981/1991). In the belly of the beast: Letters from prison. New York: Random House.

Cecil, D. (2015). Prison life in popular culture. Boulder: Lynne Rienner.

Chaplin, S. (2011). Gothic literature. London: York Press.

Conover, T. (2011). Newjack. London: Random House.

Creed, B. (1993/2007). The monstrous-feminine. Film, feminism, psychoanalysis. New York: Routledge.

Ferrell, J. (2013). Cultural criminology and the politics of meaning. Critical Criminology, 21, 257-271.

Fiddler, M. (2007). Projecting the prison: The depiction of the uncanny in The Shawshank Redemption. Crime Media Culture, 3(2), 192-206.

Fiddler, M. (2011a). A 'system of light before being a figure of stone': The phantasmagoric prison. Crime Media Culture, 7(1), 83-97.

Fiddler, M. (2011b). Superstition will add to its horrors: The early American penitentiary and its gothic shadow. The Howard Journal of Criminal Justice, 50(5), 465-477.

Fleisher, M., \& Krienert, J. (2009). The myth of prison rape: Sexual culture in American prisons. Maryland: Rowman \& Littlefield.

Garland, D. (1990/2012). Punishment and modern society. Oxford: Oxford University Press.

Hurley, K. (2007). Abject and grotesque. In C. Spooner \& E. McEvoy (Eds.), The Routledge companion to gothic. London: Routledge.

Ingebretsen, E. J. (2007). Bodies under scandal: Civic gothic as genre. In C. J. Picart \& C. Greek (Eds.), Monsters in and among us: Towards a gothic criminology. Madison: Fairleigh Dickinson University Press.

Kerman, P. (2010/2013). Orange is the new black. London: Abacus.

Kramer, L. (2000). After the lovedeath: Sexual violence and the making of culture. California: University of California Press.

Kristeva, J. (1982). Powers of horror, an essay on abjection. New York: Colombia University Press.

Pheasant-Kelly, F. (2013). Abject spaces in American cinema. London: I.B.Tauris.

Picart, J. K., \& Greek, C. (2007). Monsters in and among us: Towards a gothic criminology. Madison: Fairleigh Dickinson University Press.

Richards, S. (2013). The new school of convict criminology thrives and matures. Critical Criminology, 21(3), 375-387.

Royle, N. (2003). The uncanny. Manchester: Manchester University Press.

Sloop, J. (1996). The cultural prison: Discourse, prisoners, and punishment. Alabama: The University of Alabama Press.

Smith, P. (2008). Punishment and culture. Chicago: University of Chicago Press.

Smith, C. (2009). The prison and the American imagination. New Haven: Yale University.

Sothkott, K. (2016). Late modern ambiguity and gothic narratives of justice. Critical Criminology, 24, 431-444.

Surette, R. (2007). Gothic criminology and criminal justice policy. In C. J. Picart \& C. Greek (Eds.), Monsters in and among us: Towards a gothic criminology. Madison: Fairleigh Dickinson University Press.

Sykes, G. (1958/2007). The society of captives. A study of a maximum security prison. Princeton: Princeton University Press.

Trigg, D. (2014). The thing, a phenomenology of horror. Hants: Zero Books.

Wacquant, L. (2010). Crafting the Neoliberal state: Workfare, prisonfare and social insecurity. Sociological Forum, 25(2), 197-220. 